\title{
Dampak Profitabilitas sebagai Intervening pada Kepemilikan Institusional terhadap Kualitas Laba
}

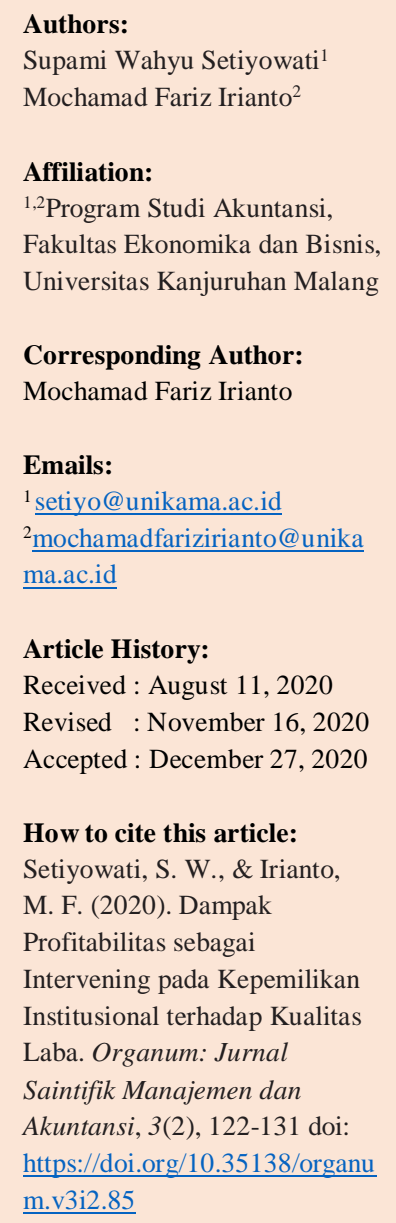

Journal Homepage: ejournal.winayamukti.ac.id/ind ex.php/Organum

\section{Copyright:}

(C) 2020. Published by

Organum: Jurnal Saintifik

Manajemen dan Akuntansi.

Faculty of Economics and

Business. Winaya Mukti

University.

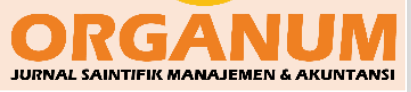

\begin{abstract}
Earnings quality refers to reported earnings to predict a firm's future earnings, which is essential for the investor's decision-making to understand its financial health. The purpose of this study was to determine the impact of profitability as an intervening variable between institutional ownership to earnings quality. This study's population was manufacturing companies in the consumer goods industry listed on the IDX for the 2017-2019 period. The sampling method is based on criteria. The samples in this study were 15 issuers. Data analysis techniques using Smart Pls. The results showed that institutional ownership affected earnings quality. Profitability was not proven as an intervening variable on the relationship between institutional ownership and earnings quality. This finding implied that institutions that had share ownership in the company increased their supervision to reduce the manager's opportunistic behaviour.
\end{abstract}

Keywords: Institutional ownership; profitability; earnings quality.

\begin{abstract}
Abstrak. Kualitas laba yakni kualitas informasi laba yang tersedia dalam umum yang dapat menjelaskan sejauh mana laba dapat memengaruhi pengambilan keputusan serta bisa digunakan oleh investor untuk menilai perusahaan. Tujuan penelitian adalah untuk mengetahui pengaruh profitabilitas sebagai intervening kepemilikan institusional terhadap kualitas laba. Populasi pada $r$ ialah perusahaan manufaktur di industri barang konsumsi yang terdaftar di BEI periode 2017-2019. Metode pengambilan sampel didasarkan pada kriteria. Sampel pada penelitian sebanyak 15 emiten. Teknik analisis data menggunakan SmartPLS. Hasil penelitian menunjukkan bahwa kepemilikan institusional memengaruhi kualitas laba. Profitabilitas berpengaruh terhadap kualitas laba. Profitabilitas tidak terbukti sebagai variabel intervening terhadap hubungan berkepemilikan institusional terhadap kualitas laba. Temuan ini membawa implikasi bahwa institusi yang memiliki kepemilikan saham di perusahaan untuk meningkatkan pengawasannya agar mengurangi perilaku oportunistis manajer.
\end{abstract}

Kata kunci: Kepemilikan institusional; profitabilitas; kualitas laba.

\section{Pendahuluan}

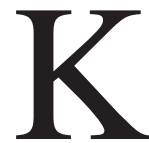
ualitas laba merupakan penilaian bagaimana laba dapat diperoleh secara terus menerus, dapat dikendalikan dan menggambarkan profitabilitas secara nyata. Kualitas laba memiliki makna kemampuan informasi pada laba yang mampu menyampaikan fenomena yang terjadi. Kualitas laba mencakup pelaporan laba saat ini yang tidak berbeda dengan laba sebelumnya (Trisnawati, 2013). Kualitas laba yang baik menunjukkan kinerja manajemen yang sebenarnya. Informasi la- 
ba sangat berguna bagi pengguna laporan keuangan. Sebaliknya, apabila kualitas laba yang rendah maka informasinya akan menyesatkan pengguna laporan keuangan, khususnya investor dan calon investor. Kasus perusahaan Garuda yang terjadi tahun 2018 merupakan bukti terjadinya praktik manipulasi laba. Laba yang dilaporkan pada 31 Desember 2018 sebesar Rp11 miliar. Sedangkan, pada tahun 2017 menderita kerugian Rp3 triliun. Makin banyaknya skandal atas informasi keuangan berdampak pada keandalan informasi keuangan yang diragukan (Prastowo, 2019).

Kepemilikan institusional yang ada di perusahaan bisa dijadikan alat pengawasan atau controlling terhadap kinerja manajemen. Kepemilikan institusional merupakan kepemilikan jumlah saham institusi yang ada di perusahaan. Adanya kepemilikan institusional diharapkan laba yang dihasilkan perusahaan merupakan laba riil yang ada di perusahaan. Laba yang riil atau nyata merupakan informasi yang penting bagi pemegang saham serta calon pemegang saham.

Perusahaan yang sedang dalam proses pertumbuhan laba merupakan perusahaan yang memberikan daya tarik investor untuk melakukan investasi. Perkembangan laba dapat memprediksi kinerja perusahaan (Handayani, 2012). Laba diperoleh perusahaan dalam aktivitas perusahaaan yang berhubungan penjualan. Kemampuan emiten dalam diperolehnya laba sangat tergantung pada jumlah penjualan, total aset, dan modal sendiri (Agus, 2010). Profitabilitas perusahaan merupakan laba yang diperoleh dari aktivitas perusahaan yang dibagi dengan total aset atau dengan modal. Tujuan dari perhitungan ini untuk melihat keefektifan aktivitas perusahaan dalam kegiatan operasional (Anjelica \& Prasetyawan, 2014). Untuk mengukur profitabilitas dapat dilakukan dengan beberapa rasio. Contoh rasio yang bisa digunakan dalam pengukuran profitabiltas adalah Gross
Profit Margin (GPM). GPM merupakan rasio untuk mengukur laba kotor dengan penjualan bersih. Net Profit Margin (NPM) rasio yang digunakan perusahaan untuk mengukur laba bersih setelah pajak (Taruh, 2012).

Berdasarkan penelitian Latif et al. (2017) yang berjudul Influence of Institutionals Ownerships on Earnings Qualitys: Evidence for Firms Listed on the Pakistan Stock Exchange, menunjukkan kepemilikan institusional berkaitan positif dengan kualitas laba. Selain itu, tingkat kepemilikan saham institusional yang sangat besar berdampak pada peningkatan pengawasan terhadap manajemen dan meningkatkan kualitas. Hertina et al. (2020) menjelaskan kepemilikan institusional tidak memengaruhi kualitas laba.

Penelitian ini sangat penting dilakukan untuk mengetahui peran kepemilikan institusional yang ada di perusahaan untuk mengawasi manajemen dalam terkelolanya sumber daya yang ada untuk menghasilkan laba yang berkualitas. Profitabilitas yang diukur menggunakan RoA, laba yang dihasilkan dengan menggunakan aset yang ada di perusahaan akan lebih mudah pengawasan yang dilakukan kepemilikan institusional daripada menggunakan sumber dana dari luar (Warrad, 2017), Risdawaty \& Subowo (2015) menjelaskan profitabilitas mempengaruhi kualitas laba. Sesuai hasil maka profitabilitas bisa dijadikan variabel intervening.

\section{Kajian Literatur}

\section{Kualitas Laba}

Kualitas laba adalah laba yang dipergunakan untuk dilakukannya penilaian yang akurat pada kinerja perusahaan saat ini. Penilaian ini digunakan sebagai landasan untuk memprediksi kinerja perusahaan di masa depan. Laba yang berkualitas mencerminkan kinerja perusahaan yang nyata (Wahlen et al., 2014). Kualitas laba yang besar dapat direalisasikan ke dalam 
kas. Kas yang ada di dalam perusahaan dapat dilihat dalam laporan arus kas. Rasio Earning Quality ialah rasio arus kas dengan laba bersih. Semakin tinggi rasio Earning Quality makin tinggi kualitas keuntungan (Ashari, 2010).

$$
\mathrm{EQ}=\frac{\text { Cash Flow Operasi }}{\text { Ebit }}
$$

\section{Kepemilikan Institusional}

Kepemilikan institusional yaitu konsentrasi saham milik institusi kepemilikan institusional dalam pengendalian pihak manajemen melalui cara memonitor dengan efektif sehingga pengurangan tindakan manajemen melakukan manajemen laba (Puspitowati \& Mulya, 2014). Adanya kepemilikan institusional dapat menambah peningkatan pengawasan sangat optimal (Maharani, 2013). Perhitungan terhadap kepemilikan institusional melalui rumus dihitung dengan rumus berikut.

Kepemilikan institusional $=$

Jumlah saham dimiliki institusional Jumlah saham yang beredar

\section{Profitabilitas}

Profitabilitas pada penelitian ini menggunakan proksi RoA. Semakin besar RoA, semakin besar pula tingkat keuntungan yang tercapai, serta makin baik pula posisi pada segi penggunaan aset. Kemampuan perusahaan dapat diukur melalui rasio tingkat penjualan, aset yang dimiliki dan modal saham tertentu (Kasmir, 2018). RoA dihitung dengan rumus berikut.

RoA $=\frac{\text { Laba bersih setelah pajak }}{\text { Total aset }} \times 100 \%$

\section{Kerangka Konseptual}

\section{Bagan 1. Kerangka Konseptual}

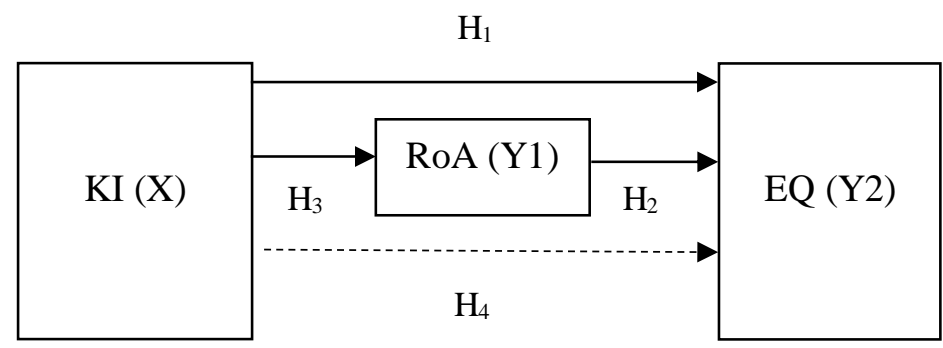

Keterangan:

\section{$\longrightarrow$ Pengaruh Langsung \\ Pengaruh tidak langsung}

\section{Hipotesis}

Konsentrasi kepemilikan institusional ialah saham emiten yang dimiliki oleh institusi maupun lembaga kepemilikan institusional memberikan peran sangat signifikan untuk meminimalisasi permasalahan agen yang terjadi pada manajer serta pemilik saham. Adanya institusional dianggap bisa menjadikan mekanisme monitor yang efektif untuk keputusan yang dibuat pada manajer. Hasil penelitian Latif et al. (2017) menunjukkan bahwa kepemilikan institusional berhubungan positif dengan kualitas laba. Selain itu, tingkat kepemilikan saham institusional yang sangat membawa banyak pengawasan serta peningkatan kualitas laba. Jadi, hipotesis diajukan dalam penelitian ini yaitu sebagai berikut.

H1: Kepemilikan institusional berpengaruh terhadap kualitas laba

Profitabilitas yaitu kemampuan perusahaan dalam pencarian laba maupun keuntungan untuk suatu tahun tertentu. Return on Asset (RoA) ialah rasio 
keuangan emiten yang berkaitan pada aspek earnings maupun profitabilitas. Fungsi RoA dalam pengukuran efektivitas emiten dalam menghasilkan laba serta pemanfaatan aset yang dimiliki. Maka bisa dimaknai emiten tersebut memiliki kualitas laba yang baik (Kasmir, 2018).

H2: Profitabilitas berpengaruh terhadap kualitas laba

Kepemilikan institusional diproksikan melalui persentase kepemilikan saham oleh institusi lain di luar perusahaan. Kepemilikan institusi yang jumlahnya besar akan berpengaruh terhadap manajemen. Pengawasan yang dilakukan institusi yang memiliki saham akan meningkatkan kualitas (Ali, 2019).

H3: Kepemilikan institusional berpengaruh terhadap profitabilitas

Konsentrasi kepemilikan institusional yaitu saham emiten yang dimiliki institusi. Kepemilikan institusional mempunyai peran penting dalam meminimalisasi permasalahan keagenan yang terjadi pada manajer serta pemilik saham. Kepemilikan institusional yang ada di perusahaan difungsikan sebagai pengawas yang efektif pada tiap keputusan yang diambil oleh manajer. Keberadaan kepemilikan institusional perusahaan bisa menghasilkan profit yang berkembang. Peningkatan profitabilitas harus seimbang dengan peningkatan kualitas laba. Penelitian Soly \& Wijaya (2017), menyatakan profitabilitas mempengaruhi kualitas laba. Latif et al. (2017) menjelaskan kepemilikan institusional berhubungan positif dengan kualitas laba.

H4: Profitabilitas sebagai intervening pada kepemilikan institusional terhadap kualitas laba

\section{Metode Penelitian}

Data yang digunakan ialah data sekunder, untuk menguji konsistensi hasil penelitian sebelumnya yang berhubungan dengan kepemilikan institusional, profitabilitas serta kualitas laba pada perusahaan manufaktur sektor konsumsi. Populasi pada riset ini ialah perusahaan manufaktur sektor barang konsumsi yang terdaftar di BEI periode 2017-2019. Sampel perusahaan dipilih sesuai kriteria. Kriteria pada penelitian ini antara lain sebagai berikut.

1. Emiten sektor konsumsi yang terdaftar di BEI yang digunakannya mata uang rupiah.

2. Emiten sektor konsumsi yang mempunyai kepemilikan institusional tahun 2017-2019.

3. Emiten sektor konsumsi yang mempunyai laba tahun 2017-2019.

Total sampel yaitu 15 emiten.

PLS didesain untuk menyelesaikan regresi berganda saat terjadi permasalahan spesifik data, seperti ukuran sampel penelitian yang kecil, adanya data yang hilang, dan terjadi multikolinearitas (Abdillah \& Hartono, 2015). Tujuan dari PLS yaitu untuk memprediksi pengaruh variabel independen terhadap variabel dependen dan menjelaskan hubungan teoretis antara kedua variabel tersebut. Berikut adalah evaluasi model PLS.

1. Model Pengukuran (Outer Model)

Model pengukuran untuk menguji validitas serta reliabilitas instrumen penelitian.

a) Uji Validitas

b) Uji Reliabilitas

2. Model Struktural (Inner Model)

Nilai koefisien path atau inner model menunjukkan tingkat signifikansi dalam pengujian hipotesis. Variabel yang diteliti adalah variabel kualitas laba (Y2), variabel Profitabilitas (Y1), dan variabel kepemilikan institusional (X).

\section{Hasil dan Pembahasan}

\section{Hasil}

Convergent validity mengukur indikator sebagai pengukur konstruk, yang dapat dilihat dari outer weight. 
Tabel 1. Hasil Pengujian Validitas

\begin{tabular}{lcc}
\hline \multicolumn{1}{c}{ Indikator } & Outer loading & AVE \\
\hline Kepemilikan Institusional & 1,000 & 1,000 \\
\hline Kualitas Laba & 1,000 & 1,000 \\
\hline ROA & 1,000 & 1,000 \\
\hline
\end{tabular}

Berdasarkan Tabel 1, hasil pengujian validitas menunjukkan bahwa nilai Average Variance Extracted (AVE) lebih besar daripada 0,5 dan rule of thumb lebih besar 0,7. Berdasarkan rule of thumb dari validitas konvergen maka dapat dikatakan bahwa indikator dari suatu variabel mempunyai korelasi tinggi terhadap variabel yang digambarkan dan indikator tersebut dikatakan valid.

Tabel 2. Hasil Pengujian Realibitas

\begin{tabular}{lcc}
\hline \multicolumn{1}{c}{ Indikator } & Cronbach's Alpha & Composite Reliability \\
\hline Kepemilikan Institusional & 1,000 & 1,000 \\
\hline Kualitas Laba & 1,000 & 1,000 \\
\hline ROA & 1,000 & 1,000 \\
\hline
\end{tabular}

Berdasarkan Tabel 2, hasil pengujian reabilitas menunjukkan nilai Cronbach's Alpha lebih besar 0,6 dan hasil composite reliability lebih besar 0,7 , maka dapat dikatakan bahwa data tersebut reliable dan dapat digunakan untuk melakukan penelitian. Dalam model PLS, nilai koefisien dari variabel endogen pada pengujian Goodness of Fit model ada pada Tabel 3 berikut.

Tabel 3. Pengujian Goodness of Fit

\begin{tabular}{|c|c|c|}
\hline Model & Variabel Endogen & $\mathbf{R}$-Square \\
\hline 1 & RoA & 0,022 \\
\hline 2 & Kualitas Laba & 0,197 \\
\hline
\end{tabular}

$$
\begin{aligned}
\text { Q-Square } & =1-\left[\left(1-\mathrm{R}^{2} 1\right) \times\left(1-\mathrm{R}^{2} 2\right)\right] \\
& =1-[(1-0,022) \times(1-0,197)] \\
& =1-(0,978 \times 0,803) \\
& =1-0,785 \\
& =0,215
\end{aligned}
$$

Berdasarkan Tabel 3, menjelaskan nilai predictive-relevance sebesar 0,215 atau $21,5 \%$. Nilai predictive relevance sebesar 21,5\% berindikasi bahwa informasi yang didapatkan dalam data $25,1 \%$ dapat dijelaskan oleh model tersebut.

\section{Pengujian Hipotesis dan Koefisien Jalur Pengaruh Langsung \\ Hasil pengaruh langsung antara} variabel bisa terlihat dari nilai koefisien jalur, $\mathrm{t}$ statistik dan p-value yang tersajikan pada Tabel 4. 
Tabel 4. Pengujian Hipotesis Pengaruh Langsung

\begin{tabular}{llllll}
\hline $\begin{array}{c}\text { Variabel } \\
\text { Bebas }\end{array}$ & $\begin{array}{l}\text { Variabel } \\
\text { Terikat }\end{array}$ & $\begin{array}{c}\text { Koefisien } \\
\text { Jalur }\end{array}$ & t statistik & p-Value & \multicolumn{1}{c}{ Keterangan } \\
\hline KI & KL & 0.308 & 2.167 & 0.031 & Signifikan \\
\hline KI & RoA & -0.150 & 1,040 & 0.299 & Tidak Signifikan \\
\hline RoA & KL & 0.370 & 2,414 & 0.016 & Signifikan \\
\hline
\end{tabular}

Gambar 1. Diagram Jalur Model Struktural dalam PLS

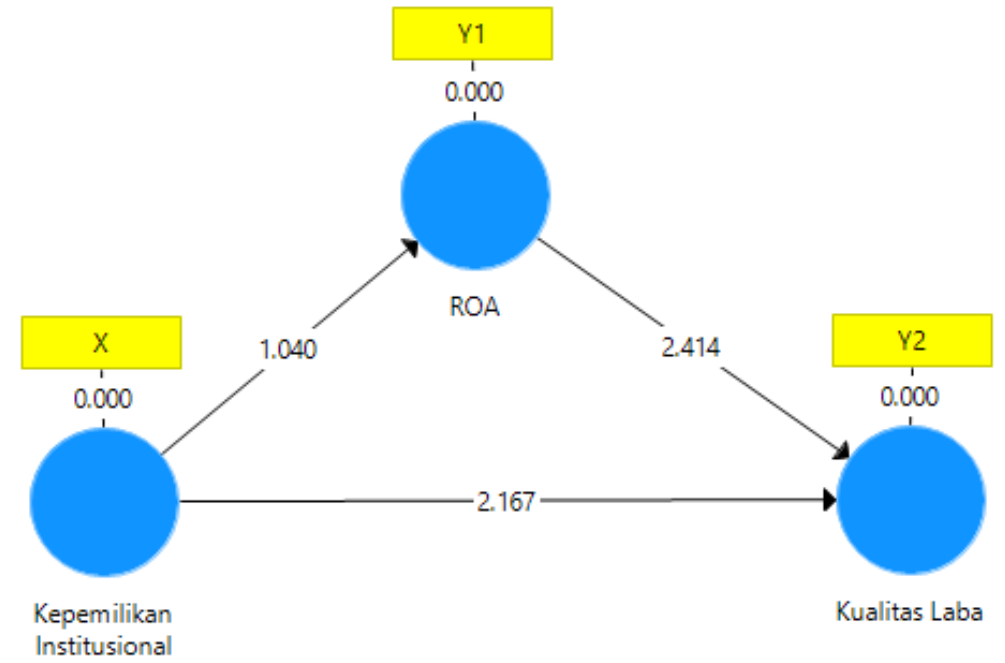

\section{Pembahasan}

Kepemilikan Institusional

Berpengaruh terhadap Kualitas Laba

Tabel 4 kepemilikan institusional mempunyai pengaruh positif signifikan pada kualitas laba dengan nilai koefisien sebesar 0,308. Perusahaan mampu mengelola biaya operasionalnya dengan baik yang berdampak pada laba. Penerapan sistem GCG yaitu kepemilikan institusional pada pengawasan perusahaan. Kepemilikan institusional mempunyai kemampuan dalam peningkatan portofolionya melalui peningkatan pengawasan pengelolaan emiten. Kepemilikan institusional yang tinggi mampu menghindari perilaku yang merugikan pihak prinsipal dan pihak manajemen. Semakin besar jumlah kepemilikan institusional semakin berkualitas profit yang dihasilkan emiten. Penelitian tersebut mendukung penelitian yang dilakukan Latif et al. (2017) yang menyatakan kepemilikan institusional memengaruhi kualitas laba.
Hasil riset bertolak belakang dengan penelitian terdahulu yang menunjukkan bahwa kepemilikan institusional tidak memengaruhi kualitas laba (Pratama \& Sunarto, 2018; Setianingsih, 2013; Yushita \& Triatmoko, 2013).

\section{Profitabilitas Berpengaruh terhadap Kualitas Laba}

Sesuai Tabel 4 profitabilitas berpengaruh positif serta signifikan pada kualitas laba dengan nilai koefisien 0,370. Perusahaan mampu mengelola sumber daya yang dimiliki secara efektif dan efisiensi sehingga menghasilkan profit yang tinggi. Laba dijadikan sebagai penentu baik atau buruknya kinerja sebuah perusahaan dalam mengelola modal yang dimiliki. Peningkatan laba yang dihasilkan dengan menggunakan aset yang ada meningkatkan kualitas yang diperoleh perusahaan.

Penelitian ini signifikan dengan penelitian sebelumnya yang menyatakan profitabilitas berpengaruh terhadap kualitas laba (Warrad, 2017; Risdawaty \& 
Subowo, 2015). Namun, penelitian ini bertolak belakang dengan penelitian Laoli \& Herawaty (2019) yang menyatakan bahwa profitabilitas memengaruhi negatif pada kualitas laba.

\section{Kepemilikan Institusional Tidak Berpengaruh terhadap Profitabilitas.}

Berdasarkan Tabel 4 menyatakan, kepemilikan institusional tidak berpengaruh terhadap profitabilitas dengan nilai koefisien sebesar -0,150. Kepemilikan institusional yakni saham yang dimiliki pihak institusi serta salah satu sistem untuk pengurangan konflik keagenan antara pihak manajemen dan kepemilikan perusahaan. Artinya makin besar kepemilikan oleh institusi maka makin besar peranan institusi dalam mekanisme GCG sehingga sisi pengawasan oleh pihak institusional terhadap kinerja manajemen makin meningkat. Penelitian tersebut konsisten serta sesuai (Rantung et al., 2019; Wiranata \& Nugrahanti, 2013) yang menyatakan kepemilikan institusional tidak memengaruhi profitabilitas. Hal ini terjadi karena pengawasan yang dilakukan kepemilikan institusional belum maksimal. Hasil penelitian ini juga bertolak belakang dengan penelitian (Sembiring \& Ibrahim, 2017).

\section{Profitabilitas sebagai Intervening pada Kepemilikan Institusional terhadap Kualitas Laba}

Profitabilitas yang diproksi oleh RoA belum mampu sebagai variabel intervening pada kepemilikan institusional terhadap kualitas laba. Kepemilikan institusional mempunyai peran penting dalam meminimalisasi permasalahan keagenan yang terjadi pada manajer serta pemilik saham. Kepemilikan institusional yang ada di perusahaan belum difungsikan sebagai pengawas yang efektif pada setiap keputusan yang diambil manajemen. Keberadaan kepemilikan institusional perusahaan belum bisa menghasilkan profit yang berkembang. Peningkatan profitabilitas harus seimbang dengan peningkatan kualitas laba.

\section{Kesimpulan}

Kepemilikan institusional berpengaruh terhadap kualitas laba. Kepemilikan institusional yang ada di perusahaan mampu menjalankan tugasnya sebagai pengawas terhadap manamen perusahaan. Kinerja manajemen meningkat diimbangi dengan kualitas laba yang meningkat. Profitabilitas yang dihasilkan dengan menggunakan aset meningkatkan kualitas laba daripada laba yang dihasilkan atas sumber dana yang didapatkan dari eksternal emiten. Hal ini dikarenakan emiten tidak akan lagi mengeluarkan biaya modal. Kepemilikan institusional belum bisa menjadi pengawas yang baik bagi pihak manajemen, hal ini terbukti belum terjadi peningkatan profitabilitas dengan adanya kepemilikan institusional yang ada di perusahaan. Profitabilitas belum mampu menjadi variabel intervening terhadap hubungan kepemilikan institusional terhadap kualitas laba, hal tersebut terjadi karena RoA yang dihasilkan emiten masih kecil sehingga belum bisa memberikan hasil yang signifikan terhadap hubungan kepemilikan institusional terhadap kualitas laba. Saran bagi peneliti berikutnya dapat menggunakan variabel lainnya dengan contoh manajemen laba sebagai variabel moderasi ataupun intervening pada faktor-faktor yang dapat memengaruhi kualitas laba.

Temuan ini membawa implikasi bahwa institusi yang memiliki kepemilikan saham di perusahaan untuk meningkatkan pengawasannya agar mengurangi perilaku oportunistis manajer.

\section{Daftar Pustaka}

\author{
Abdillah, W., \& Hartono, J. (2015). \\ Partial Least Square (PLS):
}


alternatif structural equation modeling (SEM) dalam penelitian bisnis. Yogyakarta: Penerbit Andi.

Agus, S. (2010). Manajemen Keuangan Teori dan Aplikasi (Edisi Keempat). Yogyakarta: BPFE.

Ali, M. (2019). Pengaruh Kepemilikan Institusional, Kepemilikan Saham Publik, Umur Perusahaan, Dan Ukuran Perusahaan Terhadap Profitabilitas Dengan Jumlah Bencana Alam Sebagai Moderasi. Jurnal Magister Akuntansi Trisakti, 6(1), 71-94. doi: http://dx.doi.org/10.25105/jmat.v6i 1.5068

Anjelica, K., \& Prasetyawan, A. F. (2014). Pengaruh Profitabilitas, Umur Perusahaan, Ukuran Perusahaan, Kualitas Audit, Dan Struktur Modal Terhadap Kualitas Laba. Ultima Accounting: Jurnal Ilmu Akuntansi, 6(1), 27-42. doi: https://doi.org/https://doi.org/10.31 937/akuntansi.v6i1.145

Ashari, D. (2010). Pedoman Praktis Memahami Laporan Keuangan (Tips Bagi Investor, Direksi dan Pemegang Saham). Yogyakarta: Penerbit Andi.

Handayani, N. T. (2012). Pengaruh Financial Ratio terhadap Pertumbuhan Laba dengan Pengungkapan Corporate Social Responsibility sebagai Variabel Pemoderasi. Management Analysis Journal, 1(2), 1-7. Diakses dari https://journal.unnes.ac.id/sju/index .php/maj/article/view/508

Hertina, D., Mawarnie, D., \& Ichsani, S. (2020). Profitability: Impact of Institutional Ownership, Managerial Ownership, and Capital Structure in the Agricultural Sector in Indonesia. International Journal of Psychosocial Rehabilitation, 24(2), 2848-2854. doi:
https://doi.org/10.37200/IJPR/V24I 2/PR200582

Kasmir. (2018). Analisis Laporan Keuangan. PT Raja Grafindo Persada.

Laoli, A. N., \& Herawaty, V. (2019). Pengaruh Profitabilitas, Growth, Leverage, Operating Cycle Dan Prudence Terhadap Kualitas Laba Dengan Firm Size Sebagai Variabel Moderasi'. Seminar Nasional Cendekiawan ke 5 Tahun 2019 Buku 2: Sosial dan Humaniora, pp 2-39. Diakses dari https://core.ac.uk/reader/267902157

Latif, A. W., Latif, A., \& Abdullah, F. (2017). Influence of Institutional Ownership on Earnings Quality: Evidence for Firms Listed on The Pakistan Stock Exchange. Pakistan Business Review, October. 668-687. Diakses dari https://ssrn.com/abstract=3056875

Maharani, P. O. (2013). Pengaruh Efektivitas Struktur Pengendalian Intern terhadap Kinerja Perkreditan pada Bank Perkreditan Rakyat di Kota Denpasar. E-Jurnal Akuntansi, 5(3), 666-675. Diakses dari https://ojs.unud.ac.id/index.php/Ak untansi/article/view/7662

Prastowo, Y. (2019). Kasus Garuda dan Misteri Akuntansi. Kompas.com. Diakses dari https://money.kompas.com/read/20 19/07/18/152000526/kasus-garudadan-misteri-akuntansi?page $=$ all

Pratama, A. D., \& Sunarto, S. (2018). Struktur Modal, Komisaris Independen, Kepemilikan Manajerial, Kepemilikan Institusional dan Ukuran Perusahaan terhadap Kualitas Laba. Dinamika Akuntansi, Keuangan Dan Perbankan, 7(2), 96-104. Diakses dari

https://www.unisbank.ac.id/ojs/inde x.php/fe9/article/view/7450 
Puspitowati, N. I., \& Mulya, A. A. (2014). Pengaruh Ukuran Komite Audit, Ukuran Dewan Komisaris, Kepemilikan Manajerial, dan Kepemilikan Institusional terhadap Kualitas Laba (Studi Empiris pada Perusahaan Sektor Keuangan yang Terdaftar di Bursa Efek Indonesia Periode 2008-2012). Jurnal Akuntansi Dan Keuangan, 3(1), 219-239. Diakses dari http://journal.budiluhur.ac.id/index. php/akeu/article/view/384/326

Rantung, Y., Murni, S., \& Maramis, J. B. (2019). Pengaruh Kepemilikan Institusional, Market Share, Corporate Governance Terhadap Profitabilitas Perusahaan Manufaktur Yang Terdaftar Di Bursa Efek Indonesia Periode 20132017. Jurnal EMBA: Jurnal Riset Ekonomi, Manajemen, Bisnis Dan Akuntansi, 7(3), 2681-2690. doi: https://ejournal.unsrat.ac.id/index.p hp/emba/article/view/23719/23375

Risdawaty, I. M. E., \& Subowo. (2015). Pengaruh Struktur Modal, Ukuran Perusahaan, Asimetri Informasi, dan Profitabilitas terhadap Kualitas Laba. Jurnal Dinamika Akuntansi, 7(2), 109-118. Diakses dari https://journal.unnes.ac.id/nju/index .php/jda/article/view/4121/3679

Sembiring, E. G. G. R., \& Ibrahim, M. (2017). Pengaruh Penerapan Good Corporate Governance dan Struktur Kepemilikan terhadap Profitabilitas Perusahaan (Studi pada Perusahaan Manufaktur Sektor Makanan dan Minuman yang Terdaftar di Bei Periode 2010-2014). Jurnal Online Mahasiswa (JOM) Bidang Ilmu Sosial dan Politik, 4(2). 1-18. Diakses dari https://jom.unri.ac.id/index.php/JO MFSIP/article/view/15904/15437

Setianingsih, E. P. (2013). 'Pengaruh Mekanisme Tata Kelola Perusahaan dan Kinerja Perusahaan terhadap
Kualitas Laba (Studi Kasus Perusahaan Otomotif dan Komponen di Bursa Efek Indonesia)' in Bandung: Proceeding PESAT (Psikologi, Ekonomi, Sastra, Arsitektur \& Teknik Sipil), pp 105-112. Diakses dari https://ejournal.gunadarma.ac.id/ind ex.php/pesat/article/view/976/852

Soly, N., \& Wijaya, N. (2017). FaktorFaktor yang Mempengaruhi Kualitas Laba Pada Perusahaan Manufaktur. Jurnal Bisnis Dan Akuntansi, 19(1), 47-55. doi: https://doi.org/10.34208/jba.v19i1.6 4

Taruh, V. (2012). Analisis Rasio Keuangan dalam Memprediksi Pertumbuhan Laba pada Perusahaan Manufaktur di BEI. Jurnal Pelangi Ilmu, 5(1). Diakses dari http://ejurnal.ung.ac.id/index.php/J PI/article/view/897/837

Tisnawati, A. W. (2013). Pengaruh Corporate Governance Index dan Struktur Kepemilikan terhadap Kualitas Laba Perusahaan (Studi Empiris Pada Perusahaan Peserta Corporate Governance Perception Index Tahun 2005-2010). Skripsi. Fakultas Ekonomi Universitas Sebelas Maret.

Wahlen, J. M., Baginski, S. P., \& Bradshaw, M. (2014). Financial Reporting, Financial Statement Analysis, and Valuation. Nelson Education.

Warrad, L. H. (2017). The Influence of Leverage and Profitability on Earnings Quality: Jordanian Case. International Journal of Academic Research in Business and Social Sciences, 7(10), 62-81. doi: http://dx.doi.org/10.6007/IJARBSS/ v7-i10/3359

Wiranata, Y. A., \& Nugrahanti, Y. W. (2013). Pengaruh Struktur 
Kepemilikan Terhadap Profitabilitas Perusahaan Manufaktur di Indonesia. Jurnal Akuntansi Dan Keuangan, 15(1), 15-26. doi: https://doi.org/10.9744/jak.15.1.1526

Yushita, A. N., Rahmawati \& Triatmoko, H. (2013). Pengaruh Mekanisme
Corporate Governance, Kualitas Auditor Eksternal, dan Likuiditas terhadap Kualitas Laba. Jurnal Economia, 9(2), 141-155. Diakses dari

https://journal.uny.ac.id/index.php/e conomia/article/view/1805/1497 